\title{
A NEW ANTIBIOTIC XK-62-2. III \\ THE STRUCTURE OF XK-62-2, A NEW GENTAMICIN \\ C COMPLEX ANTIBIOTIC
}

\author{
Richard S. Egan, R. Larry DeVault, Sandra L. Mueller, \\ Milton I. Levenberg, Arthur C. Sinclair \\ and Ruth S. STANASZEK
}

Division of Antibiotics and Natural Products Abbott Laboratories, North Chicago, Illinois 60064 U.S.A.

(Received for publication November 1, 1974)

\begin{abstract}
The structure of XK-62-2 has been firmly established to be $6^{\prime}-N$-methylgentamicin $\mathrm{C}_{1 \mathrm{a}}$ (3) by application of spectroscopic methods in conjunction with chemical degradation. The data obtained in every case are completely consistent with the proposed structure.
\end{abstract}

The gentamicin $\mathrm{C}$ complex ${ }^{1)}$ has been reported to consist of 3 antibiotics ${ }^{2,3)}$ designated $\mathrm{C}_{1}, \mathrm{C}_{2}$ and $\mathrm{C}_{1 \mathrm{a}}(\mathbf{1}, 2 \text { and } 4)^{4)}$. These compounds differ only in the methyl substitution pattern of the hexo- or heptopyranoses attached to the 4-position of 2-deoxystreptamine-purpurosamines $\mathrm{A}, \mathrm{B}$ and $\mathrm{C}^{5)}$. We now wish to report the structure of $\mathrm{XK}-62-2^{6,7)}$ which is $6^{\prime}-N$ methylgentamicin $\mathrm{C}_{1 \mathrm{a}}(\mathbf{3})$ the missing member of the gentamicin $\mathrm{C}$ complex. This compound completes the identification of all monoand di-methyl substituted purpurosamine compounds.

When the acid hydrolysates of XK-62-2 and gentamicins $\mathrm{C}_{1}, \mathrm{C}_{2}$ and $\mathrm{C}_{1 \mathrm{a}}$ were compared, XK-62-2 was found to contain 2deoxystreptamine and a purpurosamine which differed in $\mathrm{Rf}$ from purpurosamines $\mathrm{A}, \mathrm{B}$ and $\mathrm{C}$ as described by COOPER et al. ${ }^{5)}$ ( $c f$. Table 1). The $N$-pertrifluoroacetyl-O-pertrimethylsilyl derivative of XK-62-2 was also found to have a different retention time on

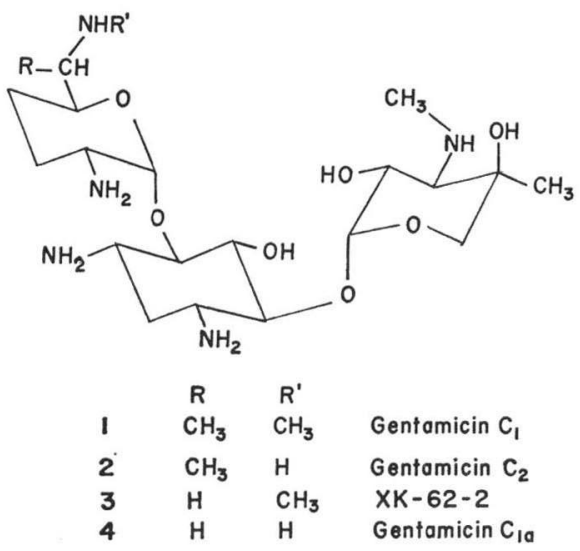

Table 1. T.L.C. Mobilities of purpurosamines

\begin{tabular}{c|c|c|c}
\hline Antibiotic & Purpurosamine & Rf-system 1* & Rf-system 2** \\
\cline { 1 - 2 } $\mathrm{C}_{1}$ & $\mathrm{~A}$ & 0.625 & 0.208 \\
$\mathrm{C}_{2}$ & $\mathrm{~B}$ & 0.575 & 0.208 \\
$\mathrm{C}_{1 \mathrm{a}}$ & $\mathrm{C}$ & 0.475 & 0.146 \\
$\mathrm{XK}-62-2$ & - & 0.550 & 0.167 \\
\hline
\end{tabular}

* Propanol-pyridine-acetic acid-water $(15: 10: 3: 12)$

** Pyridine-ethylacetate-acetic acid-water $(5: 6: 1: 3)$. Measured on cellulose

Table 2. T.L.C. Mobilities of gentamicin $\mathrm{C}$ complex

\begin{tabular}{c|c}
\hline Antibiotic & Rf* \\
\cline { 2 - 2 } $\mathrm{C}_{1 \mathrm{a}}$ & 0.45 \\
$\mathrm{C}_{2}$ & 0.51 \\
$\mathrm{XK}-62-2$ & 0.54 \\
$\mathrm{C}_{1}$ & 0.59 \\
\hline
\end{tabular}

* Methanol - chloroform - am monia (1:1:1, lower phase). Measured on Quanta Gram silica gel and detected with ninhydrin. 


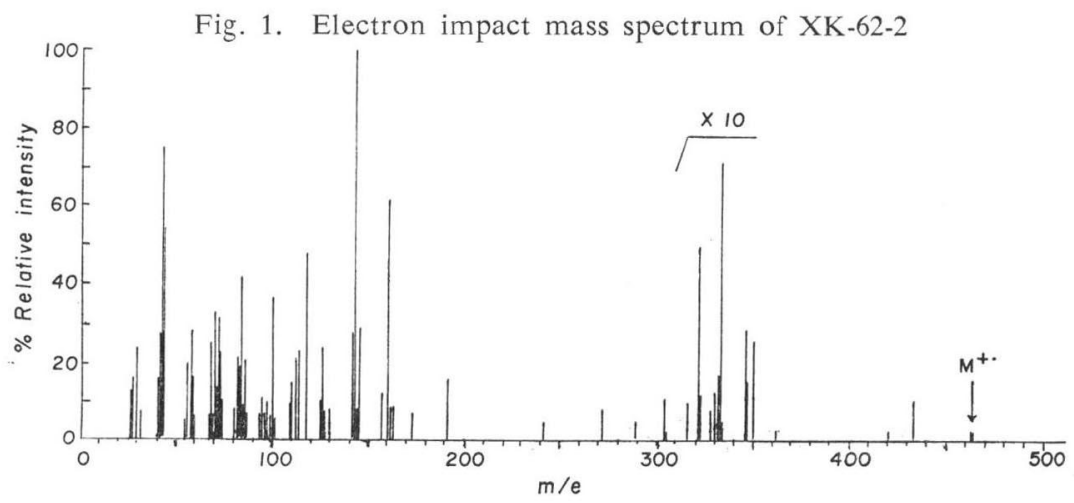

glc than the corresponding derivative of the known gentamicins.* XK-62-2 has an $\mathrm{Rf}$ slower than $\mathrm{C}_{1}$ but faster than $\mathrm{C}_{2}$ when chromatographed on silica gel developed with $\mathrm{MeOH}-\mathrm{CHCl}_{3}-\mathrm{NH}_{4} \mathrm{OH}$ (1:1:1, lower phase) ( $c f$. Table 2). Therefore the new gentamicin was postulated to be slightly more basic than $\mathrm{C}_{2}$ but less basic than $C_{1}$. Since the presence Chart 1. Mass spectral fragmentation of XK-62-2 of a methyl group on an amino substituent should increase its basisity, it was suggested that the new gentamicin was $6^{\prime}-N$-methylgentamicin $C_{1 a}$.

High resolution mass spectra were obtained for XK-62-2 and the three gentamicin $\mathrm{C}$ complex reference compounds ${ }^{8)}$. The underivatized compounds gave good spectra with prominent $\mathrm{M}^{+}$. and $(\mathrm{M}+1)^{+}$ions. The mass spectrum of XK-62-2 is shown in Fig. 1, and important fragment ions are shown in Chart 1. Empirical formulae for $\mathrm{M}^{+\cdot}$ and significant fragment ions were obtained by high-resolution data acquisition or peak matching. XK-62-2 gave<smiles>CNCC1CCC(N)C(OC2C(N)CC(N)C(OC3OCC(C)(O)C(NC)C3O)C2O)O1</smiles><smiles>CNC1C(O)C(OC2C(N)CC(N)C(OC(O)O)C2O)OCC1(C)O</smiles>

$\mathrm{C}_{14} \mathrm{H}_{28} \mathrm{~N}_{3} \mathrm{O}_{7}$
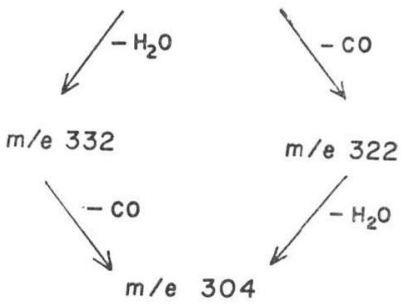

$m / e 142$<smiles>CC1CC(C)(O)C=CC1O</smiles>
$\mathrm{m} / \mathrm{e} 160$ $\mathrm{C}_{7} \mathrm{H}_{14} \mathrm{NO}_{3}$<smiles>CCCNCCO</smiles><smiles>C1CC2CCC2C1</smiles>

$\mathrm{m} / \mathrm{e} 114$ an $m / e 463\left(\mathrm{C}_{20} \mathrm{H}_{41} \mathrm{~N}_{5} \mathrm{O}_{7}\right)$ molecular ion indicating that it was isomeric with gentamicin $\mathrm{C}_{2}$. $\mathrm{A}$ peak at $m / e 160\left(\mathrm{C}_{7} \mathrm{H}_{14} \mathrm{NO}_{3}\right)$ arising from garosamine was present in all four spectra. An $m / e$ $304\left(\mathrm{C}_{13} \mathrm{H}_{26} \mathrm{~N}_{3} \mathrm{O}_{5}\right)$ fragment resulting from cleavage of the purpurosamine moiety was also present in each case suggesting that XK-62-2 and the gentamicins had identical pseudodisaccharide fragments. Compounds 1,2 and 3 all have a fragment at $m / e \quad 420\left(\mathrm{C}_{18} \mathrm{H}_{38} \mathrm{~N}_{4} \mathrm{O}_{7}\right)$ which corresponds to losses of $57\left(\mathrm{C}_{3} \mathrm{H}_{7} \mathrm{~N}\right), 43\left(\mathrm{C}_{2} \mathrm{H}_{5} \mathrm{~N}\right)$ and $43\left(\mathrm{C}_{2} \mathrm{H}_{5} \mathrm{~N}\right)$ from the respective

* R. J. Mauritz, Abbott Laboratories, manuscript in preparation. 
molecular ions. The ions at $m / e$ 463, 420,304 and 160 together, localize the differences between the various compounds to the purpurosamine ring side chain.

Numerous purpurosamine containing fragments mirror this difference in sidechain composition (a $\sim \mathbf{i}$, Chart 2 and Table 3). Most significant in the cases of XK-62-2 and gentamicin $C_{1}$ is the loss of $\mathrm{CH}_{3} \mathrm{NH}$ which suggests that both compounds have $6^{\prime}-N$-methyl substitution.

Additional evidence that firmly establishes the position of methylation was afforded by the ${ }^{13} \mathrm{C}$-nmr spectrum of XK-62-2 compared with published data $^{9)}$ of the other gentamicin C complex substances (Table 4). The chemical shifts of $\mathrm{C}-5^{\prime}$ and $\mathrm{C}-6^{\prime}$ respectively show characteristic upfield $\gamma$ - and downfield $\beta$-shifts indicative of $6^{\prime}$-methylation of gentamicin $C_{1 a}$. The remaining carbon resonances are virtually unchanged from the reference.

The ${ }^{1} \mathrm{H}-\mathrm{nmr}$ spectra of XK-62-2 and gentamicin $\mathrm{C}_{1 \mathrm{a}}$ sulfate salts (Fig. 2) reveal two anomeric proton resonances indicating that the compounds are pseudotrisaccharides. The

Table 3. Mass spectral fragmentation of gentamicin C complex. Mass of prominent ions*

\begin{tabular}{|c|c|c|c|c|c|c|c|c|c|}
\hline \multirow{2}{*}{ Compound } & \multicolumn{9}{|c|}{ Ions } \\
\hline & a & b & c & d & e & f & $\mathrm{g}$ & h & i \\
\hline 1 & - & 447 & 402 & 360 & 347 & 330 & 157 & 140 & 126 \\
\hline 2 & 446 & & 388 & 346 & 333 & 316 & 143 & 126 & 一 \\
\hline 3 & - & 433 & 388 & 346 & 333 & 316 & 143 & 126 & 112 \\
\hline 4 & 432 & - & 374 & 332 & 319 & 302 & 129 & 112 & - \\
\hline
\end{tabular}

* Identified in Chart 2

Table 4. ${ }^{13} \mathrm{C}-\mathrm{Nmr}$ data of XK-62-2 (3) and gentamicin $\mathrm{C}_{1 \mathrm{a}}$ (4)

\begin{tabular}{|c|c|c|c|c|c|c|c|c|}
\hline & 3 & 4 & & 3 & 4 & & 3 & 4 \\
\hline $\mathrm{C}-1$ & 51.5 & 51.7 & $\mathrm{C}-1^{\prime}$ & 101.2 & 102.2 & $\mathrm{C}-1^{\prime \prime}$ & 101.2 & 101.3 \\
\hline $\mathrm{C}-2$ & 36.5 & 36.7 & $\mathrm{C}-2^{\prime}$ & 50.5 & 51.0 & $\mathrm{C}-2^{\prime \prime}$ & 70.1 & 70.2 \\
\hline $\mathrm{C}-3$ & 50.3 & 50.6 & $\mathrm{C}-3^{\prime}$ & 26.5 & 27.1 & $\mathrm{C}-3^{\prime \prime}$ & 64.2 & 64.4 \\
\hline $\mathrm{C}-4$ & 87.7 & 88.3 & $\mathrm{C}-4^{\prime}$ & 28.5 & 28.5 & $\mathrm{C}-4^{\prime \prime}$ & 73.1 & 73.3 \\
\hline $\mathrm{C}-5$ & 75.4 & 75.4 & $\mathrm{C}-5^{\prime}$ & 68.5 & 71.5 & $\mathrm{C}-5^{\prime \prime}$ & 68.1 & 68.7 \\
\hline \multirow[t]{2}{*}{$C-6$} & 86.9 & 87.8 & $C-6^{\prime}$ & 55.1 & 46.0 & $3^{\prime \prime}-\mathrm{NCH}_{3}$ & 37.7 & 38.0 \\
\hline & & & $6^{\prime}-\mathrm{NCH}_{3}$ & 35.3 & - & $4^{\prime \prime}-\mathrm{CCH}_{3}$ & 22.5 & 23.0 \\
\hline
\end{tabular}

Chart 2. Mass spectral fragmentation of gentamicin C complex

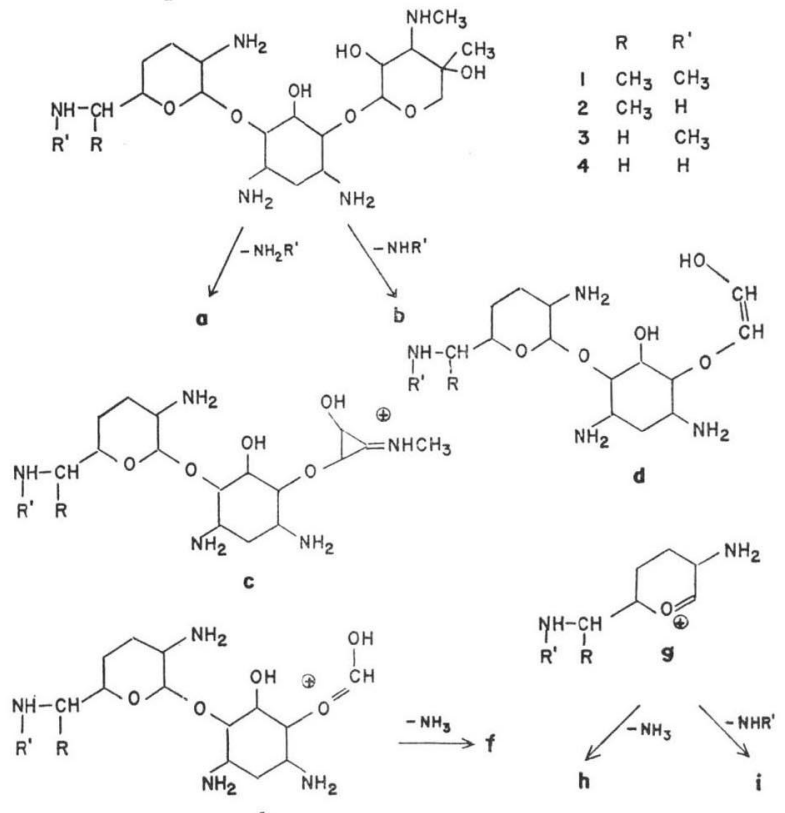


$5.62 \mathrm{ppm}$ anomeric resonance of gentamicin $\mathrm{C}_{1 \mathrm{a}}$ sulfate is attributable to garosamine on the basis of spin decoupling experiments which locate the resonance of $\mathrm{H}-2^{\prime \prime}$ at $4.70 \mathrm{ppm}$ as a doublet of doublets $\left(\mathrm{J}_{1^{\prime \prime}, 2^{\prime \prime}}=3.5 \mathrm{~Hz}, \mathrm{~J}_{2^{\prime \prime}, 3^{\prime \prime}}=11.0 \mathrm{~Hz}\right)$ and the resonance of $\mathrm{H}-3^{\prime \prime}$ as a simple

Fig. 2. ${ }^{1} \mathrm{H}-\mathrm{Nmr}$ spectrum of gentamicin $\mathrm{C}_{1 \mathrm{a}}$ sulfate (top) and $\mathrm{XK}-62-2$ sulfate (bottom) in $\mathrm{D}_{2} \mathrm{O}$ solution
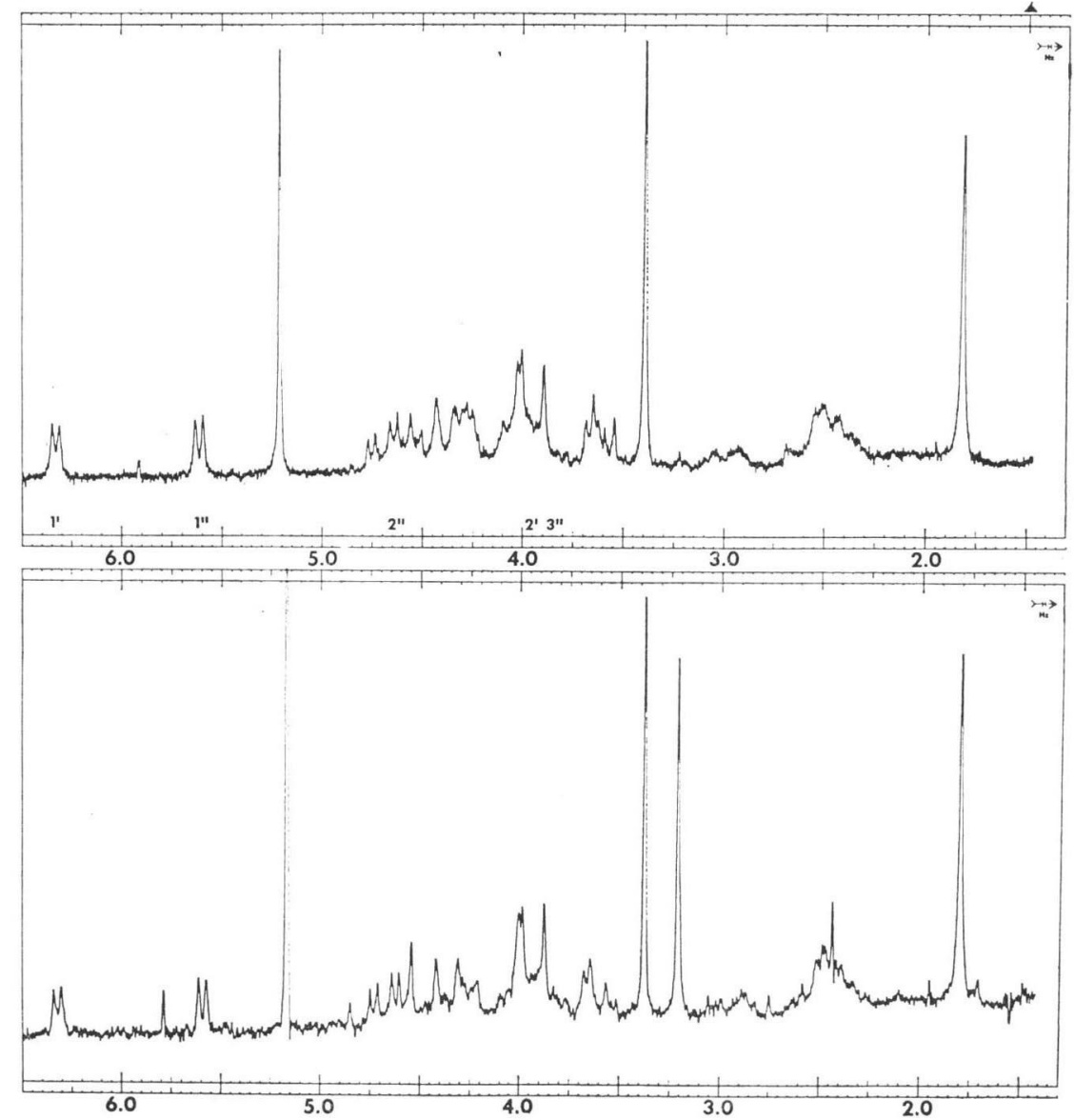

doublet at $3.95 \mathrm{ppm}$. The lack of a second coupling for $\mathrm{H}-3^{\prime \prime}$ indicates that the $4^{\prime \prime}$-position is tertiary as is expected in garosamine. A protonated $N$-methyl singlet at $3.38 \mathrm{ppm}$ and a tertiary $C$-methyl singlet at $1.80 \mathrm{ppm}$ are also attributable to garosamine present in both compounds.

The patterns of the ring proton resonances between 2.0 and 5.0 ppm are unchanged indicating that no change in carbon skeletons has occurred. The only significant difference between the two spectra is the presence of an additional protonated $N$-methyl singlet at 3.21 ppm in the spectrum of XK-62-2 sulfate. This singlet can be attributed to a $6^{\prime}-N$-methyl substituent of the purpurosamine. The absence of an upfield $C$-methyl doublet in the spectrum of $\mathrm{XK}-62-2$ sulfate indicates that this compound, like gentamicin $\mathrm{C}_{1 \mathrm{a}}$, does not contain the 6'-C-methyl purpurosamine found in gentamicin $\mathrm{C}_{1}$ or $\mathrm{C}_{2}$. 


\section{Comment}

It is appropriate at this point to comment on the probable relationship between XK-62-2 and the material isolated by KeRSHNER and designated gentamicin $\mathrm{C}_{2 \mathrm{a}}{ }^{10)}$. Critical to the proof of structure offered by KERSHNER are mass spectral and $\mathrm{nmr}$ spectral analyses. The published interpretation of the nmr spectrum of gentamicin $\mathrm{C}_{2 \mathrm{a}}$ includes the controversial report that the resonance of the $6^{\prime}-N$-methyl group appears as a doublet due to coupling with the $\mathrm{NH}$ proton which was possible because of slow exchange in $\mathrm{D}_{2} \mathrm{O}$ solution. Examination of the published spectrum supports an alternate explanation that the doubling of peaks is a consequence of the presence of substantial amounts of other compounds-most likely gentamicin $C_{1}$. The published gentamine $C_{2 a}$ spectrum clearly reveals a similar lack of purity.

A stronger basis for KERSHNER's conclusion is his mass spectral data ${ }^{10,11)}$ which are essentially identical to that which we report. Particularly noteworthy is the loss of $\mathrm{CH}_{3} \mathrm{NH}$ from the parent ion as confirmed by metastable defocussing. It remains possible however, in light of the close structural similarities of the components of the gentamicin $\mathrm{C}$ complex, that substantial amounts of contaminant could go undetected by mass spectrometry.

In summary although it appears likely that a portion of the mixture isolated and studied by KERSHNER is identical with our XK-62-2 the proof based on his published data is not unambiguous.

\section{Experimental}

Mass spectra were obtained on an A.E.I. MS-902 spectrometer at $50 \mathrm{eV}$ and $170^{\circ} \mathrm{C}$ using the direct insertion probe. ${ }^{1} \mathrm{H}-\mathrm{nmr}$ spectra were measured on a Varian Associates HA-100 spectrometer in $\mathrm{D}_{2} \mathrm{O}$ solution. Chemical shifts are reported in ppm downfield from external TMS contained in the inner tube of a Wilmad Co-axial cell assembly. ${ }^{13} \mathrm{C}-\mathrm{Nmr}$ were measured on a Varian Associates XL-100 spectrometer in $\mathrm{D}_{2} \mathrm{O}$ solution. Chemical shifts were measured from internal dioxane $(67.4 \mathrm{ppm})$ and are reported in ppm downfield from TMS. The authors are indebted to Dr. D. Hillenbrand, University of Wisconsin for the ${ }^{13} \mathrm{C}-\mathrm{nmr}$ data.

Acid Hydrolysis A $1.0 \mathrm{mg}$ portion of XK-62-2 was suspended in $0.1 \mathrm{ml} 6 \mathrm{~N} \mathrm{HCl}$, sealed in a small glass tube, and placed in an oven at $110^{\circ} \mathrm{C}$ for $17 \sim 24$ hours. The solution was transferred to a round-bottom flask with water and evaporated several times from $\mathrm{H}_{2} \mathrm{O}$ to remove excess $\mathrm{HCl}$. The residue was finally suspended in $0.1 \mathrm{ml} \mathrm{H}_{2} \mathrm{O}$ and $2 \mu \mathrm{l}$ was spotted per chromatogram.

\section{References}

1) Weinstein, M. J.; G. M. Luedemann, E. M. Oden \& G. H. Wagman: Gentamicin, a new broad spectrum antibiotic complex. Antimicr. Agents \& Chemoth. -1963: 1 13, 1964

2) Weinstein, M. J.; G. H. Wagman, E. M. Oden \& J. A. Marquez: Biological activity of the antibiotic components of the gentamicin complex. J. Bact. 94: 789 790, 1967

3) Wagman, G. H.; J. A. Marquez \& M. J. Weinstein: Chromatographic separation of the components of the gentamicin complex. J. Chromatogr. 34: 210 215, 1968

4) Cooper, D. J.; P. J.L. Daniels, M. D. Yudis, H. M. Marigliano, R. D. Guthrie \& S. T. K. BukHari: The gross structures of the gentamicin C components. J. Chem. Soc. (C) 1971: $3126 \sim 3129,1971$

5) Cooper, D. J.; M. D. Yudis, H. M. Marigliano \& T. Traubel: The purpurosamines, a new class of naturally occurring 2, 6-diaminomonosaccharides. J. Chem. Soc. (C) 1971: 2876 2879, 1971

6) OKachi, R.; I. Kawamoto, S. Takasawa, M. Yamamoto, S. Sato, T. Sato \& T. Nara: A new antibiotic XK-62-2: I. Isolation, physicochemical and antibacterial properties. J. Antibiotics 27: $793 \sim 800,1974$

7) Nara, T.; I. Kawamoto, R. Okachi, S. Takasawa, M. Yamamoto, S. Sato, T. Sato \& A. 
Morikawa: New antibiotic XK-62-2 (sagamicin). II. Taxonomy of the producing organism, fermentative production and characterization of sagamicin. J. Antibiotics 28: 21 28, 1975

8) Daniels, P. J. L.; M. Kugelman, A. K. Mallams, R. W. Tkach, H. F. Vernag, J. Weinstein \& A. Yehaskel: Mass spectral studies on aminoglycoside antibiotics. Chem. Comm. 1971: $1629 \sim 1631,1971$

9) Morton, J. B.; R. C. Long, P. J. L. Daniels, R. W. Tkach \& J. H. Goldstein: A carbon-13 magnetic resonance study of aminoglycoside pseudotrisaccharides. The gentamicin antibiotics. J. Amer. Chem. Soc. 95: 7464 7469, 1973

10) Kershner, A.S.: Separation, structural and physical studies on the gentamicin C complex. Ph. D. Thesis, Rutgers, The State Univ., New Brunswick, N.J., 1971

11) Rinehart, K. L., Jr.; P. Schaefer, J. L. Cook, C. P. Schaffner \& A. Kershner: Mass spectrometric characterization of aminocyclitol antibiotics. 19th Am. Conf. on Mass Spectrometry and Allied Topics, May 2 7, 1971, Atlanta, Ga., Am. Soc. for Mass Spectrometry. 